\title{
Synchronic Study about Chinese and Western Government Administrative Ideas: Distinction and Cause
}

\author{
Li Pengfei * Tang Qingmeng \\ School of Public Administration, Yunnan University of Finance and Economics, Yunnan, P. R. China, 650221 \\ (Email:Lpf28@126.com, 540843078@qq.com)
}

\begin{abstract}
An administrative idea is the soul of the administrative act and the core of the ruling culture. For a country's government, administrative ideas determine its administrative function, organization, system and mode. The core values of China and Western countries have been the focal point to the culture researchers since ancient times, especially the Philosophical foundations and history of different countries. Chinese government administration, from the doctrine of the Mean philosophy and the history of agricultural civilization, derived some core ideas such as harmony, benevolent governance, rule of virtue, grade, rule of man, and power tactics. Western government administration, from the thought of liberal philosophy and the development of industrial civilization, must derive the core ideas like freedom, justice, democracy, rule of law, and efficiency. These differences of core administrative ideas are caused by the differences among philosophical basis, historic culture and economic system.
\end{abstract}

Keywords: Administrative idea; Distinction; Motivation; Cause.

\section{The Hard-core Administrative Ideas of Chinese Government 1.1 Harmony}

"Harmony" originated from the administrative idea "Neutralization" in Chinese philosophy and Confucian culture, it is not only the Chinese wisdom to deal with complex relationships, but also the first value for government to deal with the country and the state relations. Harmony is a state of equalization that all things in the middle of positive and negative. Harmony does not exclude the diversity of things, nor the differences, antagonism, competition, struggle or even war, but it believes that they can be governed by a universality, cohesion and centripetal force. In terms of the relationship among the humans or the countries, this kind of universality is the human nature which transcends skin, region, nation, state, and will would last forever. However, what do the humans desire to maintain their own existence and development is cohesion and a centripetal force. Harmony embodies Chinese ways of thinking about unity of opposites which contains Monismand Pluralism, otherness and compatibility. It also depicts everything in its place with happiness knowing no bounds. From the perspective of system science, harmony is an equilibrium state in nature and human society. As for the things of real state, balance is temporary and relative, disequilibrium is eternal, universal norm. But humans exist in the universe and strive for the balance between humans and the nature. Disequilibrium will lead to the human and the nature against each other, make the inside of the human society apart, even lead to the destruction of human beings. Harmony is widespread embedded in Chinese psyche especially for "Meme" and "Collective Unconsciousness"; it's also the way of thinking and standard of behavior for government and citizens to deal with complex problems. 1

\subsection{Benevolent Government}

People know that the philosophical foundation of government administration is "harmony", but the thing is, how could the government achieve it? In Chinese history, the political ideology of Confucianism gave a "prescription" called "kingly way". It referred to a political view that rules the world must put virtue on the first point, it also 
required government to love their people and protect them. To have done this, the people-oriented government finally got supports from the people. Therefore, the government made and put policy, law and system into force. This is the "benevolent governance". Just as its name implies, "benevolent governance" is lenient, tolerant and grateful polity and administration. Taxpayers pay taxes to support the government, so the government has responsibility to report back on what has been done. It is also based on inherent human nature which thirsts for the justice. Nowadays, "benevolent governance", in conformity with the principle of Mencius' "goodness", is pursued by Chinese government as the core values without doubt.

\subsection{Rule of Virtue}

What are the requirements for the government officials? Chinese Confucian's answer is "rule of virtue". The Confucian advocates educating and influencing people by morality. Also Confucius deems that, regardless of the human nature of good or evil, people could all get moralization. In order to educate the public well, the government officials are requested to own the noble moral sentiment, setting a good example and earnestly practicing what they advocate. The public is supposed to follow the example and know their places. The official virtue includes "propriety" that centers on "principle of feudal moral conduct" and "moral foundations of society" advocated by Confucian, reflecting the pecking order. In modern governance of China, "propriety" has been transformed to a large extent, but "rule of virtue" still exists in someone's subconscious, especially for the elders. "Rule of law" is another momentous way for Chinese administration in addition to "rule of virtue", But in the Chinese political culture, "morality given priority over penalty" has been internalized as an administrative principle followed by the government all the time.

\subsection{Rank}

How to guarantee the "rule of law" in a long run? At this time, ranking order was required to be built in the government system. According to the administrative level, in the core of ranking order, officials were classified. Administrative level further fortifies the "Official-Oriented standard". Now, the Chinese government still persists in the administrative idea of hierarchical Confucian thinking substance. Government agencies do "top-down" administration in rank order, and officials give expression to the socalled "value" through administrative level. Government officials administrate in the light of rank order, thus leading to malfeasance such as corruption.

\subsection{Power Tactics}

In traditional political culture of China, the "power tactics" is not the political values of Confucian but Legalism. Shang Yang put it as "law", Shen Dao regarded it as "power-base", Shen Buhai said it "method". Although Legalism failed to become the mainstream of Chinese political culture, it didn't hamper the "power tactics" to be the administrative value for officials. "Power tactics" refers to the statecrafts, skills, even stratagems used by officials above the law and morality, and it's also an administrative method or "hidden rule" that objectively exists in the government system. In reality, officials who used the "power tactics" have got abundant material and spiritual resources, so the ignorant people or sideliners scramble for it imminently. In the hierarchical system of government, apart from relying on its own official virtue, and administrating according to law, officials 
take the "power tactics" as an important value of politics and administration.

\section{The Hard-core Administrative Ideas of Western}

\section{Government}

\subsection{Freedom}

Freedom is foundation of political philosophy of administrative philosophy in the west, western political philosophy think that freedom is a fundamental human nature. Freedom is the original meaning of a person's thinking and behavior without any external force. It is commonly referred to "say what I want to say, do what I want to do", which is absolutely free. But people are gregarious animals living, government have to use morality, law, and system to regulate people's thinking and behavior, people have to be regulated by law, morality and system, Freedom is relative freedom that restricted by law, morality and system. In western cultural context, this relative freedom is said to be a kind of social status and social ideals, which makes people to meet their own desires and realize self-realization without fear, slavery and harm. The ultimate purpose of government is to safeguard the existence of absolute freedom of people, and everything that restricts absolutely freedom of people is evil. Depending on this, for freedom, the government itself is evil. Under morality and law, the real freedomis relative, absolute freedom means "should" out of requirement of human nature. Hence the presence of the government is actually to ensure that changes from relative freedom to absolute freedom.

\subsection{Justice}

Since any individual is living in the population, can only enjoys relative freedom, then enjoying relative freedom should be fair for every individual. Because if the injustice, there will be chaos in the whole society, this judgment is directly related with the jealousy which is one of basic human nature. According to Aristotle's argument, justice is distributive justice, distributive justice is divided into two kinds, and one is completely justice, that some kind of social resources should be equally distributed to individuals without discrimination, such as human rights. Another is the proportional justice, that community resources should be allocated according to contribution in addition to human rights, namely contribution to society is only three points, the resources one can get are only three points, two points or four points assigned to him are injustice. ${ }^{2}$ Justice actually also means justice for exchange, equal rights and obligations means justice for exchange; For individuals and others, the individual's rights is the obligation of others, that is justice if they are equal, and vice versa.

\subsection{Democracy}

In order to achieve social justice, which requires democracy? Considering from self-interest, one of human nature, people do not believe that they would be given deserve justice from the government under the leadership of a person, hence it needs citizens to participate in, negotiate, bargain, develop and implement rules that everyone recognized, namely system. In the modern context, democracy is by all citizens, directly or indirectly freely elected representatives to exercise the administrative power of the government organization form. Democracy is fundamental principles and behavior to protect the human liberty. It is institutionalized performance of freedom. Majority make a decision, while respecting individual rights of minority, which is the principle of democracy. In modern society, all democratic countries respect the wishes of the majority of people, while try to protect the fundamental rights of individuals and minorities. Democracy is not only an 
administrative concept, but also an administrative system and administrative methods and techniques.

\subsection{Rule of Law}

The rule of law is a legal belief which points that, in a society, the law has the status of all above. No one could be above the law. On the premise of democracy, the rule of law takes acting by law as rational principle, and assumes the unification between legal order and spirit of law which contains the intrinsic value. "Rule of law" in the west was firstly formed in ancient Greece. Aristotle summed up the current situation of the ancient Greek cities under different regimes and law enforcements, then come to the conclusion that the "rule of law should be better than that of the rule of man". Because the law was made by the majority of people together, "the rule of law" can meet the needs of most people, more to justice rather than groups, so he thought that "the rule of law" is fairer than "rule of man". The thinker of ancient Rome, Cicero, using a "dumb consul" metaphor for the law in his "legal chapter", developed "the rule of law". He thought the country's behavior should be restricted by law, and state governance activities should be carried out within the scope of the law. When the bourgeois enlightenment, enlightenment thinkers, represented by Rousseau and Montesquieu, advocated "the rule of law" and against the feudal privilege, which laid the foundation of the bourgeois legal system. In the modern west, government administration still adheres to the rule of law. First is to further improve the content of the law and ensure the morality, justice and validity of law; then is to assure the implementation of the law by coercive force of the state.

\subsection{Efficiency}

Western countries always attach great importance to the "efficiency", whether in the field of market economy or governance. Their governments especially emphasize the performance management, performance appraisal and incentive control, by means of marketing, organizational innovation, competition, and performance to reengineer the government, in pursuit of maximizing efficiency. The theory of new public administration suggested that, more attention from the government is not investment, but more output and performance management activities. Government should care the efficiency and quality in the process of providing public services directly, and responds to the change of outside more actively and more flexibility. During western governance practice, they advocate to build "Entrepreneurial Government", that is about to introduce management methods and techniques of private sector into the government in order to increase the administrative efficiency.

\section{The Cause of the Government Administrative} Ideas Difference between China and the West

\subsection{Different Philosophical Basis}

Chinese administrative ideas are based on the philosophy of the Moderation which was known as "the virtue of a saint" by Confucius. Moderation is not only a kind of life wisdom or we say a kind of personal integrity, but also a concentrated reflection of equilibrium. Meanwhile, it's also the best state of things before the qualitative change, as well as before the collapse or jump of a system. The golden mean is meanwhile a kind of leadership thinking art in political philosophy, requesting people's words and deeds to be reasonable and fair. It admonishes administrators to deal with interpersonal relationship by a smart way, in order to solve complex problems. The doctrine of the mean infiltrates into Chinese administrative ideas, deriving brilliant administrative branches like "harmony", "Benevolent government", 
and "rule of virtue". We can see from the illustrations above, the moderation relationship is a kind of political assumption originated from the view of the people.

Western administrative ideas are based on the liberalistic philosophy. The ancient Greek Socrates, Plato and modern enlightenment philosophers have always been the advocates of liberalism. John Locke mentioned: "we know that, God would never let anyone be in the circumstance of being controlled by the rest, he could make his own living without following any others' commands. Being the Lord and Father of all human beings, gives no privileges to any of his offspring." ${ }^{3}$ No privilege would carry forward democracy and freedom. This kind of administrative idea which formed on the basis of liberalism will more likely be accepted by citizens. Freedom emphasizes more on the idea of being FREE, but not perfection or limitation. In such a free environment, different thoughts can game and discuss with each other, then forming a more novel administrative idea that also applies to their specific national conditions.

\subsection{Different Historical Culture}

China started with the authoritarian political complexion, which lasted, unfailingly, for thousands of years and the regime and political system were quite complete, and formed a set of matching political thoughts and ideas. Confucianism was the most important school of thought, which had exerted the most enormous and profound impact on China. Confucius advocates "benevolent governance", "moral ruling", "people-oriented" ideas and so on, which not only was suitable for the authorities, also provided ideas for references for today's Chinese government. Confucius advocates " Harmony being the most precious" and the ideology of "neutralism" was continued to develop all the time, as well as inherited by today's government innovation and development to the concept of "harmony" and apply to the government administration. At the same time, Confucianism emphasizes the concept of "hierarchy", which was also inherited and giving the concept bigger updating on the perspective of content.

Western political culture development has experienced the penetrations of freedom, equality, and democracy in the ancient Greek and Roman period, of the religious reform of the Middle Ages, the Renaissance, of the free development of capitalism to monopoly, of the two world wars to contemporary hegemonism and power politics. ${ }^{4}$ In the ancient period, the power of rulers came from the citizens. How to coordinate citizens and society, and the relation between power and right is the main theme of the ancient Greek thinkers. This requires the constraint of regime, as early as then has created the concept of "rule of law". Under the political regime in Roman republic, the separation of powers, checks and balances of governance principles, were sprouted in the political system, which is the opposite of China's authoritarian system. Western advocates the principle of separation of powers and checks and balances, to very great degree, catalyzed and highlighted the management idea of the "democracy" and "justice".

\subsection{Different Economic System}

China was under a planned economy, and the government managed economy and society through the mandatory plans and administrative means. At that time, the government which played the role of the rulers was omnipotent, and the function of providing public services had been diluted. In this kind of economic system, the idea of rule became stronger. Officials were classified by rank, and they used "power tactics" to gain and consolidate their 
authority. At the beginning of the socialist market economy, the economic system failed to remold traditional administrative ideas, because the decisive effect from market to act on the allocation of resources didn't come true. With the development of the society and the impact of globalization, traditional planned economy system gradually collapsed, and the socialist market economy gradually produced and developed. Combined with the infiltration and influence of western administrative ideas, Chinese consciousness of the rights had been improved unprecedentedly, and the function of the government gradually transferred to provide public services. Simultaneously, the idea of "rule of law" got strengthened, "ruling the country by virtue" couldn't meet the present stage of the government and the development of the society.

For the developed countries whose economies are Market economy-oriented, the responsibility of public affairs management was borne by the government and NGOs. Market economic system emphasized justice and guided by the interests. Under this system, modern administrative ideas were forced. In the context of globalization with rapidly changing and various challenges, the countries under the market economic system are requested to be more efficient. The government needs to deal with public affairs more timely, flexibly and effectively.

\section{References}

(1) Aristotle. (2010) Nichomachean Ethics [M]. People's Publishing House, 147-147

(2) John, Locke. (1997). Government (First Treatise) [M].The Commercial Press, 36-37.

(3) Li, Pengfei. (2006).The Theory to Construct Administrative Relationship of Harmony [J]. China: Hubei Academy of Social Sciences, 11
(4) Xu,Datong. (1985). History of Western Political Thoughts [M]. China: Tianjin People's Publishing House, 273-305 